\title{
Identification of dipeptidyl peptidase-IV inhibitory peptides from mare whey protein hydrolysates
}

\author{
J. J. Song, ${ }^{*} \dagger$ Q. Wang, $\dagger$ M. Du, ${ }^{*} \ddagger$ X. M. Ji, $\dagger$ and X. Y. Mao* $\dagger^{1}$ \\ ${ }^{*}$ Beijing Advanced Innovation Center for Food Nutrition and Human Health, College of Food Science \& Nutritional Engineering, \\ China Agricultural University, Beijing 100083, China \\ tKey Laboratory of Functional Dairy, Ministry of Education, College of Food Science and Nutritional Engineering, China Agricultural University, \\ Beijing 100083, China \\ ‡Department of Animal Sciences, Washington State University, Pullman 99163
}

\section{ABSTRACT}

Inhibition of dipeptidyl peptidase-IV (DPP-IV) activity is a promising strategy for treatment of type 2 diabetes. In the current study, DPP-IV inhibitory peptides were identified from mare whey protein hydrolysates obtained by papain. The results showed that all the mare whey protein hydrolysates obtained at various hydrolysis durations possessed more potent DPP-IV inhibitory activity compared with intact whey protein. The 4-h hydrolysates showed the greatest DPP-IV inhibitory activity with half-maximal inhibitory concentration of $0.18 \mathrm{mg} / \mathrm{mL}$. The 2 novel peptides from $4-\mathrm{h}$ hydrolysate fractions separated by successive chromatographic steps were characterized by liquid chromatography-electrospray ionization tandem mass spectrometry. The novel peptides Asn-Leu-Glu-Ile-Ile-Leu-Arg and Thr-Gln-Met-Val-Asp-Glu-Glu-Ile-Met-Glu-Lys-Phe-

Arg, which corresponded to $\beta$-lactoglobulin $1 \mathrm{f}(71-77)$ and $\beta$-lactoglobulin $1 \mathrm{f}(143-155)$, demonstrated DPPIV inhibitory activity with half-maximal inhibitory concentrations of 86.34 and $69.84 \mu M$, respectively. The DPP-IV inhibitory activity of the 2 peptides was retained or even improved after simulated gastrointestinal digestion in vitro. Our findings indicate that mare whey protein-derived peptides may possess potential as functional food ingredients in the management of type 2 diabetes.

Key words: dipeptidyl peptidase IV, mare milk, whey protein, bioactive peptide

\section{INTRODUCTION}

Type 2 diabetes mellitus is a worldwide metabolic disorder and is one of the leading public health problems, which is increasing at an explosive rate. Globally,

Received August 5, 2016.

Accepted December 15, 2016.

${ }^{1}$ Corresponding author: wumaoxy@163.com an estimated 382 million people were affected by type 2 diabetes in 2013 and this number is predicted to reach 592 million by 2035 (International Diabetes Federation, 2013; Guariguata et al., 2014). Type 2 diabetes is characterized by insulin resistance and pancreatic $\beta$-cell dysfunction, which can result in severe complications such as nephropathy, retinopathy, cardiovascular disease, and peripheral vascular disease (Deshpande et al., 2008; Alonso-Magdalena et al., 2010). Therefore, effective interventions that may delay or prevent the onset of type 2 diabetes have attracted increasing attention.

Different therapies for type 2 diabetes have been proposed during the past decades. Among these treatments, a novel therapeutic strategy is targeting incretin hormones, which include glucagon-like peptide-1 and glucose-dependent insulinotropic peptide. These hormones are secreted from the small intestine within several minutes after food ingestion and subsequently promote glucose-dependent insulin secretion from pancreatic islet $\beta$-cells (Drucker, 2006; Tulipano et al., 2011). Moreover, they inhibit $\beta$-cell apoptosis and enhance $\beta$-cell proliferation (Khan et al., 2013). The increased levels of glucagon-like peptide-1 and glucosedependent insulinotropic peptide improve glucose tolerance in normal and diabetic rats (Higuchi et al., 2013). However, incretin hormones are metabolized rapidly in vivo by endogenous protease dipeptidyl peptidase-IV (DPP-IV; EC 3.4.14.5; Hatanaka et al., 2012; Zambrowicz et al., 2015). Therefore, additional supplementation of DPP-IV inhibitors can extend incretin action and thereby enhance insulin secretion, which has been regarded as one of the newest treatments for type 2 diabetes (Nauck et al., 2009). To inhibit DPP-IV, several synthetic inhibitors, such as vildagliptin and sitagliptin, have been developed for the treatment of type 2 diabetes over the past decade (Pratley et al., 2006; Karasik et al., 2008; Lacroix and Li-Chan, 2013). However, adverse side effects of these synthetic inhibitors are noted, such as upper respiratory tract infections, nasopharyngitis, and headaches (Reid, 2012). Thus, 
there is an increased focus on identifying natural DPPIV inhibitors for the management of type 2 diabetes.

Whey protein dietary supplements improve obesityrelated blood pressure, vascular function, fatty liver disease, and type 2 diabetes (Pal and Ellis, 2010; Shertzer et al., 2011). Several peptides derived from bovine whey proteins have been shown to possess antihypertensive activity, antiinflammatory activity, and antioxidant activity (Wang et al., 2012; de Carvalho-Silva et al., 2014; Brandelli et al., 2015). Bovine whey proteinderived peptides inhibit DPP-IV activity in vitro (Lacroix and Li-Chan, 2013, 2014). Moreover, DPP-IV inhibitory peptides derived from bovine $\beta$-LG decrease blood glucose levels after an oral glucose tolerance test in C57BL/6 mice (Uchida et al., 2011). In addition, preservation of active incretin hormones by DPP-IV inhibitory peptides generated during gastrointestinal digestion of whey proteins is considered to be associated with the insulinogenic and glucose-lowering effects of whey protein in vivo (Jakubowicz and Froy, 2013).

Mare milk is a traditional foodstuff consumed in Mongolia and southern states of the former Soviet Union (Uniacke-Lowe et al., 2010). Also, in several European countries, such as Germany, Italy, and the Netherlands, the production and consumption of mare milk have gained importance, and approximately 1 million kilograms of mare milk is produced in Europe (Fox and Uniacke, 2010). It is reported that 30 million individuals regularly consume mare milk all over the world (Martuzzi and Vaccari Simonini, 2010). This increased interest in consuming mare milk is considered to be associated with special nutritional and therapeutic properties of mare milk. It has a positive influence on bowel flora, metabolic disorders, stiff joints, and cancer, which benefits the diets of the elderly, convalescent, or newborn (Uniacke-Lowe et al., 2010; Rad et al., 2013). The whey protein content in mare milk is 8.3 $\mathrm{g} / \mathrm{kg}$ of milk, which is higher than those in bovine milk (5.7 g/ $\mathrm{kg}$ of milk; Malacarne et al., 2002). Although mare $\alpha$-LA is similar to bovine $\alpha$-LA in terms of AA sequence, mare $\beta$-LG possesses only $58 \%$ identity with bovine $\beta$-LG (El-Salam and El-Shibiny, 2013). Based on the difference in the AA profiles between mare whey and bovine whey, bioactive peptides from 2 types of whey proteins are expected to be different. However, mare whey proteins as a source of bioactive peptides have not been studied.

In the current study, mare whey protein hydrolysates were prepared by incubating with papain for different durations, and their DPP-IV inhibitory activities were evaluated in vitro. The hydrolysates with the greatest DPP-IV inhibitory activity were fractioned by successive chromatographic steps, and peptides were further identified by liquid chromatography-electrospray ion- ization tandem mass spectrometry (LC-ESI MS/ MS).

\section{MATERIALS AND METHODS}

\section{Materials and Reagents}

Mare milk was sampled in a traditional pasture area, Inner Mongolia, China. Papain (EC 3.4.22.21, from papaya latex, 0.5-2.0 units/mg), pepsin (EC 3.4.23.1, from porcine gastric mucosa, 250 units per milligram), pancreatin (from porcine pancreas, $8 \times$ UPS), GlyPro-p-nitroanilide (H-Gly-Pro-pNA·HCl), dipeptidyl peptidase-IV (EC 3.4.14.5, from porcine kidney, $\geq 10$ units per milligram), and diprotin A (Ile-Pro-Ile) were purchased from Sigma-Aldrich (St. Louis, MO). The HPLC-grade acetonitrile, trifluoroacetic acid, and formic acid were from Fisher Scientific (Fair Lawn, NJ). All other chemicals used in the study were of analytical grade.

\section{Isolation of Mare Whey Proteins}

Mare milk was defatted by centrifugation at 5,000 $\times$ $g$ at $10^{\circ} \mathrm{C}$ for $30 \mathrm{~min}$. The mare casein was precipitated from skim mare milk at $\mathrm{pH} 4.6$ with $10 \%$ (vol/vol) acetic acid by centrifuging at $5,000 \times g$ for $30 \mathrm{~min}$ at $10^{\circ} \mathrm{C}$. The supernatant containing whey proteins was dialyzed for $48 \mathrm{~h}$ and freeze-dried. The protein content in protein lyophilizates was determined by Kjeldahl method, as previously described (Finete et al., 2013). The protein content was $71.27 \pm 0.59 \%$ (nitrogen-protein conversion factor, 6.38).

\section{Preparation of Mare Whey Protein Hydrolysates}

Lyophilized mare whey was dissolved in distilled water at a concentration of $5 \%(\mathrm{wt} / \mathrm{vol})$. The solutions were adjusted to $\mathrm{pH} 6.0$ and preincubated at $55^{\circ} \mathrm{C}$ for $10 \mathrm{~min}$. The papain enzyme was added ( $5 \%$ enzyme/ substrate ratio on a wt/wt protein basis) to hydrolyze the whey protein with a constant temperature and $\mathrm{pH}$. Hydrolysates of mare whey proteins were collected at $0,0.25,0.5,0.75,1,2,3,4$, and $5 \mathrm{~h}$. These hydrolysate samples were heated to $85^{\circ} \mathrm{C}$ and maintained for 15 min to inactivate protease, followed by centrifugation at $1,800 \times g$ at $4^{\circ} \mathrm{C}$ for 20 min with TGL-20M high-speed centrifuge (Pingfan Instrument Co. Ltd., Changsha, China). The supernatants were collected and ultrafiltered using an Ultracel Amicon model 8400 ultrafiltration unit (Millipore Corporation, Bedford, MA) with membranes of molecular weight cutoffs of 10 $\mathrm{kDa}$. The $<10 \mathrm{kDa}$ fraction was collected and freeze- 
dried, and was defined as mare whey protein hydrolysates.

\section{Determination of DPP-IV Inhibition Activity}

The inhibitory activity of samples against DPP-IV was assayed as previously described with minor modifications (Van et al., 2009; Nongonierma and FitzGerald, 2014). Briefly, lyophilized samples were resuspended in Tris-HCl buffer (100 $\mathrm{mM}, \mathrm{pH}$ 8.0). In a well of a 96-well microplate, $20 \mu \mathrm{L}$ of sample solution and $100 \mu \mathrm{L}$ of substrate solution (H-Gly-Pro-pNA·HCl, final concentration $0.5 \mathrm{mM}$ ) were added. The enzyme reaction was started by adding $30 \mu \mathrm{L}$ of DPP-IV (final concentration $0.0075 \mathrm{U} / \mathrm{mL}$ ). The absorbance at $405 \mathrm{~nm}$ was monitored after the microplate was incubated at $37^{\circ} \mathrm{C}$ for 0.5 h. The DPP-IV inhibitory activity (\%) was calculated as follows:

$$
\begin{aligned}
& \text { DPP-IV inhibitory activity }(\%)= \\
& {\left[\begin{array}{c}
\text { Absorbance }(\text { test sample })- \\
1-\frac{\text { Absorbance }(\text { sample control) }}{\text { Absorbance }(\text { negative reaction })-} \\
\text { Absorbance (negative control) }
\end{array}\right] \times 100,}
\end{aligned}
$$

where Absorbance(test sample) was the absorbance at $405 \mathrm{~nm}$ in the presence of Tris-HCl buffer, DPP-IV, H-Gly-Pro-pNA·HCl, and sample; Absorbance(sample control) was the absorbance at $405 \mathrm{~nm}$ when DPP-IV was replaced with Tris-HCl buffer; Absorbance(negative reaction) was the absorbance at $405 \mathrm{~nm}$ when sample was replaced with Tris- $\mathrm{HCl}$ buffer; and Absorbance(negative control) was the absorbance at $405 \mathrm{~nm}$ when DPP-IV and sample were replaced with Tris-HCl buffer.

The half-maximal inhibitory concentration $\left(\mathbf{I C}_{50}\right)$ value was defined as the concentration of sample that inhibited $50 \%$ of DPP-IV activity and was calculated by the logarithmic regression of DPP-IV inhibitory activity against the concentration of the sample.

\section{Purification of DPP-IV Inhibitory Peptides}

Separation by Gel Filtration Chromatography. Mare whey protein hydrolysate with the highest DPP-IV inhibitory activity was separated using gel permeation chromatography, as previously described (Huang et al., 2012). Briefly, the lyophilized hydrolysate $(20 \mathrm{mg})$ was dissolved in $1 \mathrm{~mL}$ of deionized water and fractionated by gel filtration on a Sephadex G-25 column $(2.5 \mathrm{~cm} \times 70 \mathrm{~cm}$, GE Healthcare Bio-Science $\mathrm{AB}$, Beijing, China) equilibrated and eluted with de- ionized water. Fractions of $3 \mathrm{~mL}$ were collected at the flow rate of $0.6 \mathrm{~mL} / \mathrm{min}$ and the absorbance at $220 \mathrm{~nm}$ was monitored to separate peptide fractions. To obtain enough samples for further analysis, the separation was repeated 10 times. Each fraction was lyophilized and its DPP-IV inhibitory activity was determined.

Separation by HPLC. The fractionated peptide from gel permeation chromatography exhibiting the highest DPP-IV inhibitory activity was purified by HPLC (model LC-10AT, Shimadzu, Japan), as previously described with minor modifications (Lacroix and Li-Chan, 2014). The lyophilized fraction was dissolved in ultra-pure water to a concentration of $2 \mathrm{mg} / \mathrm{mL}$ and injected into a column (Eclipse XDB-C18, $4.6 \mathrm{~mm} \times$ $250 \mathrm{~mm}, 5 \mu \mathrm{m}$, Agilent Technologies Inc., Shanghai, China). The sample was eluted with a linear gradient of acetonitrile (10-90\% (vol/vol) in $30 \mathrm{~min})$ and $0.1 \%$ trifluoroacetic acid (vol/vol) in $\mathrm{H}_{2} \mathrm{O}$ under a flow rate of 1 $\mathrm{mL} / \mathrm{min}$ at $30^{\circ} \mathrm{C}$. The elution was monitored at $220 \mathrm{~nm}$ with a UV/visible detector. Fractions eluting from 6 to 15 min were collected every minute, and the separation was performed 10 times to obtain enough samples for analysis. After removing acetonitrile by evaporation, these fractions were freeze-dried and assayed for their DPP-IV inhibitory activities.

\section{Identification of AA Sequence by LC-ESI MS/MS}

The purified peptide fraction displaying the greatest DPP-IV inhibitory activity was analyzed by LC-ESI MS/MS with a nanoAcquity nano HPLC system (Waters, Milford, MA), which was directly interfaced with a Q Exactive mass spectrometer (Thermo Scientific, Waltham, MA), as previously described (Zhang et al., 2015). Briefly, the sample was injected into a trap column $(100 \mu \mathrm{m} \times 20 \mathrm{~mm}$, Polymicro Technologies, Phoenix, AZ) packed with Aqua C18 column (5 $\mu \mathrm{m}$ particle size, $125 \AA$, Phenomenex, Torrance, CA) and separated on a micro analytical column $(50 \mu \mathrm{m} \times 10$ $\mathrm{cm}$, Polymicro Technologies) packed with Aqua C18 column (3 $\mathrm{m}$ particle size, $125 \AA$, Phenomenex). The eluting program was performed using a linear gradient of acetonitrile [1-40\% ( $\mathrm{vol} / \mathrm{vol})$ in $40 \mathrm{~min}]$ and $0.1 \%$ ( vol/vol) formic acid in water at a flow rate of 200 $\mathrm{nL} / \mathrm{min}$. The eluate was directly injected into the MS system. The MS analysis was carried out in positive ion mode and full scans were performed for Auto MS/ MS between 100 and 2,500 m/z. The acquired MS/ MS data were preprocessed with Mascot Distiller 2.4 (MatrixScience, London, UK). The AA sequences of peptides were identified by comparison with identified peptide sequences from Equus caballus whey proteins (UniProt database, http://www.uniprot.org/). 


\section{Peptide Synthesis}

Peptides identified by LC-ESI MS/MS were prepared by the conventional Fmoc solid-phase synthesis method, which were performed by Nanjing Leon Biological Technology Co. Ltd. (Nanjing, China). The purity of the peptides was $\geq 95 \%$.

\section{Simulated Gastrointestinal Digestion of Synthetic Peptides}

The synthetic peptides were subjected to simulated gastrointestinal digestion, as described previously (Walsh et al., 2004). Peptides were dissolved in deionized water, and the $\mathrm{pH}$ value of solution was adjusted to 2.0 with $1 \mathrm{M} \mathrm{HCl}$. Pepsin (enzyme to substrate mass ratio of 1:40) was added to hydrolyze the peptides. The hydrolysis reaction was performed at $37^{\circ} \mathrm{C}$ in a shaking incubator. After $1.5 \mathrm{~h}$, the $\mathrm{pH}$ value of solution was adjusted to 7.5 with $1 \mathrm{M} \mathrm{NaOH}$. Then, pancreatin at an enzyme/substrate mass ratio of $1 / 100$ was added to the solution, which was incubated at $37^{\circ} \mathrm{C}$ for $2.5 \mathrm{~h}$ with shaking. Afterward, the solution was heated at $80^{\circ} \mathrm{C}$ for 20 min to terminate digestion. The digested peptides were lyophilized and then resuspended in Tris- $\mathrm{HCl}$ buffer $(100 \mathrm{mM}, \mathrm{pH} 8.0)$ at a final concentration of 0.5 $\mathrm{mg} / \mathrm{mL}$ to determine their DPP-IV inhibitory activity.

\section{Statistical Analysis}

All assays in the present study were performed at least in triplicate and data were expressed as means \pm standard deviations. Significant differences $(P<0.05)$ between means were identified by Tukey's procedures using SPSS software (version 20.0, IBM Inc., Chicago, IL).

\section{RESULTS}

\section{DPP-IV Inhibitory Activity of Mare Whey Hydrolysates}

As shown in Figure 1A, compared with intact mare whey (5.26 $\pm 0.21 \%$ inhibition), the obtained mare whey hydrolysates showed more potent DPP-IV inhibitory activity at a concentration of $1.0 \mathrm{mg} / \mathrm{mL}(53.25$ $\pm 1.70 \%$ to $77.25 \pm 1.60 \%$ inhibition), which varied depending on the hydrolysis durations. The 4-h hydrolysate displayed the greatest DPP-IV inhibitory activity $(77.25 \pm 1.60 \%$ inhibition), and its inhibitory activity increased dose-dependently from 0.025 to $1.0 \mathrm{mg} /$ $\mathrm{mL}$ (Figure $1 \mathrm{~B}$ ). The $\mathrm{IC}_{50}$ value of the 4 -h hydrolysate was $0.18 \mathrm{mg} / \mathrm{mL}$. In addition, Ile-Pro-Ile was used as a reference inhibitor in our study. The $\mathrm{IC}_{50}$ value of the Ile-Pro-Ile was $10.45 \mu \mathrm{M}$.

\section{DPP-IV Inhibitory Activity of Mare Whey Hydrolysates Fractionated by Gel Filtration Chromatography and HPLC}

The 4-h hydrolysates were fractionated using a Sephadex G-25 gel filtration column, and 2 fractions, F1 and F2, were collected, which corresponded to fractions from 60 to $125 \mathrm{~min}$ and fractions from 130 to $210 \mathrm{~min}$, respectively (Figure 2A). Compared with unseparated 4-h hydrolysates, the obtained 2 fractions showed more potent DPP-IV inhibitory activity, with inhibitory rates of $49.16 \pm 3.56 \%$ and $67.46 \pm 0.59 \%$ at a concentration of $0.1 \mathrm{mg} / \mathrm{mL}$, respectively (Figure 2B). Therefore, the F2 fraction with higher DPP-IV inhibitory activity was lyophilized and used for further purification by HPLC. Several minor peaks were observed between the retention time from 6 to $15 \mathrm{~min}$, as shown in Figure 3A. Thus, 9 fractions from the minor peaks every $1 \mathrm{~min}$ (F2-1 to F2-9) were collected, lyophilized, and used to determine their DPP-IV inhibitory activity. Fraction F2-7 showed the greatest DPP-IV inhibition rate of $38.33 \pm 0.79 \%$ and was selected to identify peptide sequences (Figure 3B).

\section{Identification of DPP-IV Inhibitory Peptides}

To identify the AA sequence of the peptides with potent DPP-IV inhibitory activity, the F2-7 fraction with the greatest DPP-IV inhibitory activity was analyzed by LC-ESI MS/MS. As an example, the LC-ESI MS/MS spectrum of a double-charged ion with $m / z$ at 435.77 was shown in Figure 4. Following sequence interpretation and database searching, the LC-ESI MS/ MS spectrum of ion with $m / z 870.54$ was matched to sequence Asn-Leu-Glu-Ile-Ile-Leu-Arg (NLEIILR). A total of 5 peptides with lengths ranging from 6 to 13 AA were identified from the F2-7 fraction (Table 1). Two of them originated from $\beta$-LG and 3 peptides were from $\alpha$-LA (Figure 5).

\section{DPP-IV Inhibitory Activity of Selected Synthetic Peptides}

It is reported that DPP-IV inhibitory peptides are generally characterized by a hydrophobic character (Boots, 2012). Moreover, the presence of positively charged Lys residue at the carboxyl-terminal end of peptides reduces the hydrophobic characteristics of peptides and thereby decreases the inhibition effect against DPP-IV (Yin et al., 2012; Silveira et al., 2013). Based on these structural features of DPP-IV inhibitory peptides, 2 of the peptides identified by LC-ESI MS/MS were selected for chemical synthesis and $\mathrm{IC}_{50}$ values against DPP-IV of the 2 synthetic peptides 
were determined. Table 2 shows that the $\mathrm{IC}_{50}$ values of Asn-Leu-Glu-Ile-Ile-Leu-Arg (NLEIILR) and ThrGln-Met-Val-Asp-Glu-Glu-Ile-Met-Glu-Lys-Phe-Arg (TQMVDEEIMEKFR) against DPP-IV were 86.34 and $69.84 \mu M$, respectively. The tri-peptide diprotin $\mathrm{A}$ (Ile-Pro-Ile) was used as a reference inhibitor, and its $\mathrm{IC}_{50}$ value was $10.45 \mu \mathrm{M}$ in the current study.
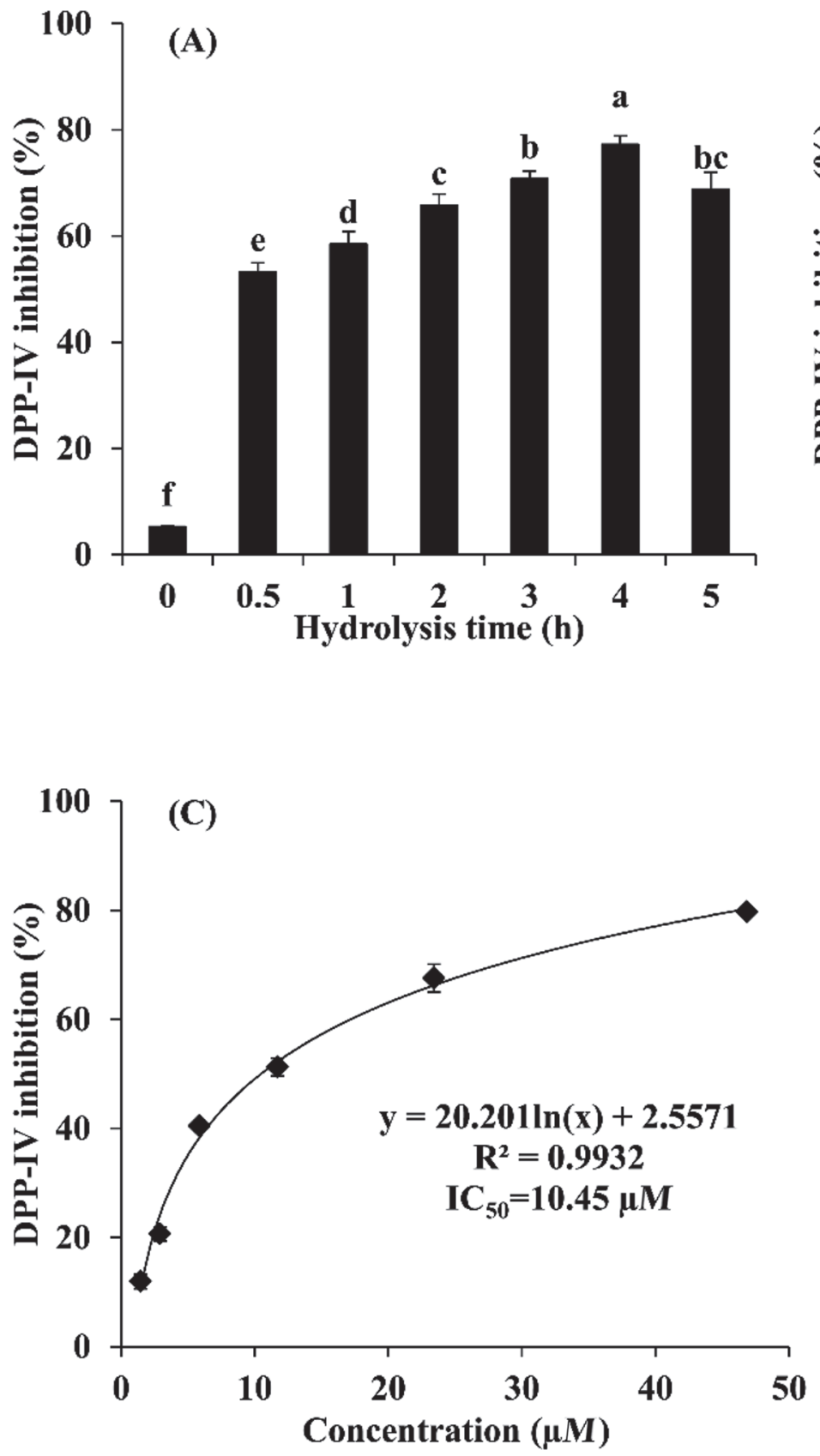

\section{Simulated Gastrointestinal Stability of Selected Synthetic Peptides}

The DPP-IV inhibitory activity of 2 synthetic peptides and diprotin A before and after in vitro simulated gastrointestinal digestion was determined. As shown in Table 3, before simulated gastrointestinal digestion, the

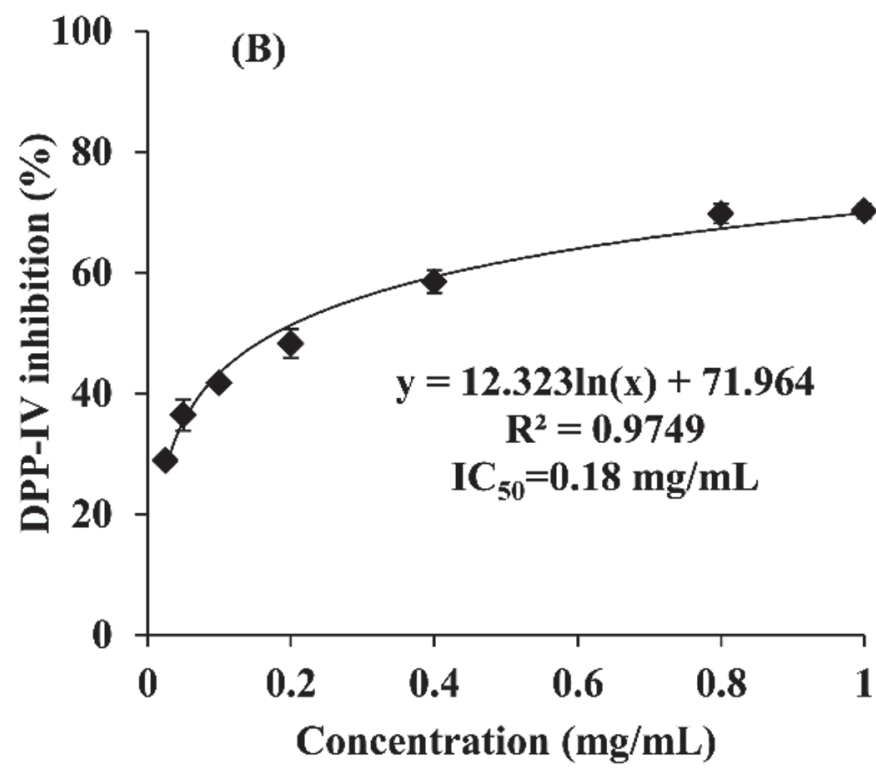

Figure 1. Dipeptidyl peptidase-IV (DPP-IV) inhibitory activity of mare whey protein hydrolysates and Ile-Pro-Ile. (A) Mare whey protein was hydrolyzed with papain (enzyme/substrate ratio $=5 \%, 0-5 \mathrm{~h}$ ). The DPP-IV inhibition rate was measured using $1.0 \mathrm{mg} / \mathrm{mL}$ of hydrolysate (final assay concentration, protein basis). (B) DPP-IV inhibition rate and half-maximal inhibitory concentration ( $\mathrm{IC}_{50}$ ) value of 4-h papain hydrolysate at various concentrations. The DPP-IV inhibition rate is regressed on $\ln (\mathrm{x})$ of concentration. (C) DPP-IV inhibition rate and $\mathrm{IC}_{50}$ value of Ile-Pro-Ile at various concentrations. The DPP-IV inhibition rate is regressed on $\ln (\mathrm{x})$ of concentration. Values are expressed as means $\pm \mathrm{SD}$ of 3 independent determinations. Different letters indicate significant differences $(P<0.05)$. 
DPP-IV inhibition of NLEIILR, TQMVDEEIMEKFR, and diprotin A was $54.86 \pm 2.71 \%, 63.14 \pm 0.55 \%$, and $38.77 \pm 0.90 \%$ at a concentration of $0.5 \mathrm{mg} / \mathrm{mL}$, $0.5 \mathrm{mg} / \mathrm{mL}$, and $2 \mu \mathrm{g} / \mathrm{mL}$, respectively. The DPP-IV inhibitory activity of NLEIILR and diprotin A nonsignificantly changed before and after simulated gastrointestinal digestion. However, the inhibition effect of TQMVDEEIMEKFR against DPP-IV increased by $21.00 \%$ after simulated gastrointestinal digestion.

\section{DISCUSSION}

Incretins are gut-derived enteroendocrine hormones released into the bloodstream in response to ingested food. They increase glucose-dependent insulin secretion
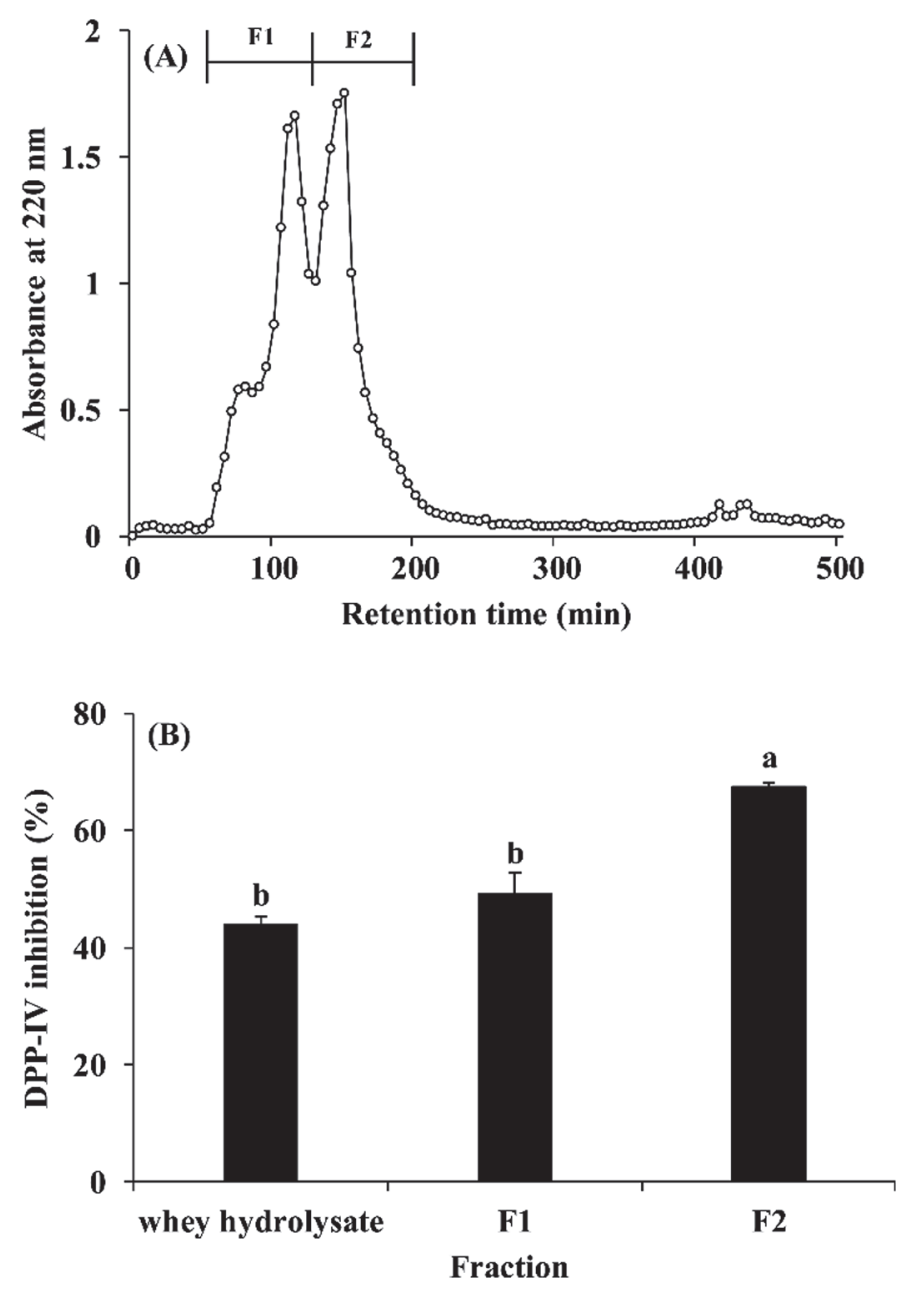

Figure 2. Elution profile (A) and dipeptidyl peptidase-IV (DPPIV) inhibitory activity (B) of mare whey protein hydrolysate fractions (F) obtained by Sephadex G-25 (GE Healthcare Bio-Science AB, Beijing, China) gel filtration chromatography. The DPP-IV inhibition rate was determined using a $0.1 \mathrm{mg} / \mathrm{mL}$ sample (final assay concentration). Values are expressed as means $\pm \mathrm{SD}$ of 3 independent determinations. Different letters indicate significant differences $(P<0.05)$.
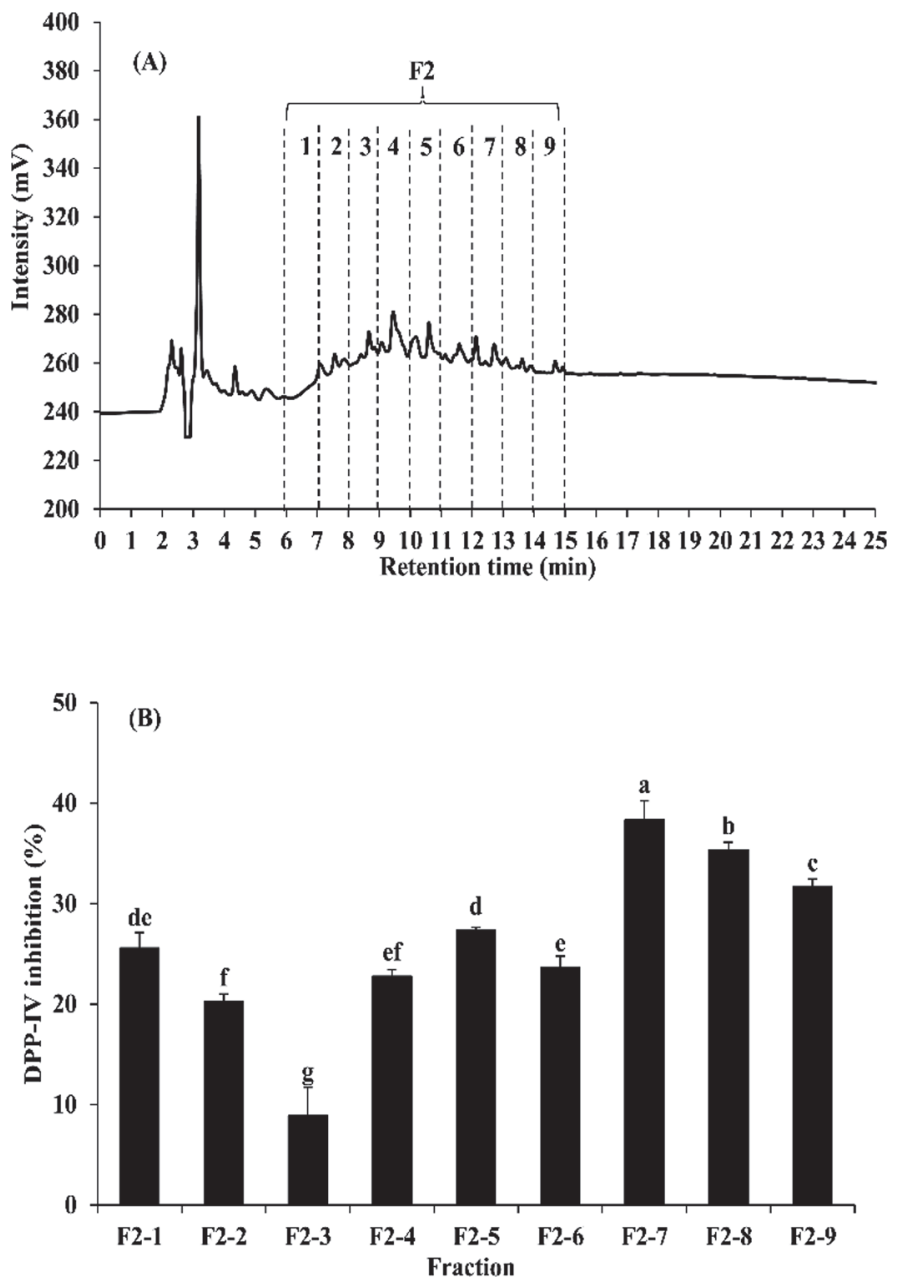

Figure 3. High-performance liquid chromatography profile of F2 fractions from Sephadex G-25 (GE Healthcare Bio-Science AB, Beijing, China) gel filtration chromatography (A) and dipeptidyl peptidase-IV (DPP-IV) inhibitory activity of associated fractions (B). The DPP-IV inhibition rate was determined using a $0.025 \mathrm{mg} / \mathrm{mL}$ sample (final assay concentration). Values are expressed as means \pm $\mathrm{SD}$ of 3 independent determinations. Different letters indicate the significant differences $(P<0.05)$.

from pancreatic $\beta$-cells. About two-thirds of the insulin secreted after an oral glucose load is elicited by incretin hormones (Holst and Gromada, 2004). Increased blood levels of incretins and insulin effectively lower blood glucose levels in type 2 diabetic mice (Zhang et al., 2013). However, the cleavage and inactivation of incretins happen within several minutes due to the presence of DPP-IV. Inhibition of incretin degradation by DPPIV inhibitor enhances insulin secretion and improves glycemic control in diabetic rats (Hsieh et al., 2015). Thus, DPP-IV inhibitors may possess a potential for the treatment of type 2 diabetes. In the present study, 4-h mare whey protein hydrolysates produced by papain possessed potent DPP-IV inhibitory activity in 
Table 1. Liquid chromatography-electrospray ionization tandem MS identification of dipeptidyl peptidase-IV (DPP-IV) inhibitory peptides in fraction F2-7 obtained by HPLC

\begin{tabular}{lrrl}
\hline Sequence & $\begin{array}{c}\text { Calculated } \\
\text { mass }(\mathrm{Da})\end{array}$ & $\begin{array}{c}\text { Observed molecular } \\
\text { ion, } m / z \text { (charge) }\end{array}$ & Origin \\
\hline NLEIILR & 870.05 & $435.77(2) / 870.54(1)$ & $\beta$-LG f $(71-77)$ \\
TQMVDEEIMEKFR & $1,655.90$ & $828.39(2) / 1,655.78(1)$ & $\beta$-LG f (143-155) \\
SMDGYK & 699.77 & $350.65(2) / 700.29(1)$ & $\alpha$-LA f $(14-19)$ \\
NNGKTEYG & 881.90 & $441.70(2) / 882.39(1)$ & $\alpha$-LA f $(44-51)$ \\
YDTQTIVK & 967.09 & $484.26(2) / 967.51(1)$ & $\alpha$-LA f $(36-43)$ \\
\hline
\end{tabular}

vitro with $\mathrm{IC}_{50}$ value of $0.18 \mathrm{mg} / \mathrm{mL}$, which was lower than that of bovine whey protein hydrolysates generated with a foodgrade pancreatic enzyme preparation $(1.34 \mathrm{mg} / \mathrm{mL}$; Nongonierma and FitzGerald, 2013). This difference is mainly attributed to different peptide profiles of the hydrolysates, which is associated with the difference of the used proteases and protein sources (Zhang et al., 2016). To the best of our knowledge, this is the first time that mare whey protein hydrolysates are reported for their DPP-IV inhibitory properties.

Previous studies have reported that bioactive peptides contribute to DPP-IV inhibitory activity of protein hydrolysates. The hexapeptide Val-Ala-Gly-Thr-TrpTyr $\left(\mathrm{IC}_{50}\right.$ value, $\left.174 \mu M\right)$ is found to be responsible for the DPP-IV inhibitory activity of $\beta-\mathrm{LG}$ hydrolysates (Uchida et al., 2011). Moreover, Atlantic salmon skin gelatin-derived peptides with an $\mathrm{IC}_{50}$ value of $1.35 \mathrm{mg} /$
$\mathrm{mL}$ have been identified as Gly-Pro-Ala-Glu and GlyPro-Gly-Ala, and possess a superior antidiabetic effect in streptozocin-induced diabetic rats at a dose of 300 mg per day (Li-Chan et al., 2012; Hsieh et al., 2015). In our study, 2 peptides, Asn-Leu-Glu-Ile-Ile-Leu-Arg and Thr-Gln-Met-Val-Asp-Glu-Glu-Ile-Met-Glu-LysPhe-Arg, were identified in 4-h mare whey protein hydrolysates. The $\mathrm{IC}_{50}$ values against DPP-IV of them were 86.34 and $69.84 \mu M$, respectively, suggesting that these 2 peptides may be responsible for the DPP-IV inhibitory activity of mare whey hydrolysates. Moreover, to our knowledge, the 2 identified peptides were first experimentally demonstrated to possess DPPIV inhibitory activity, and the AA sequence of the 2 identified peptides only existed in mare whey protein, not in bovine whey protein. In addition, we found no significant difference in DPP-IV inhibitory activity of

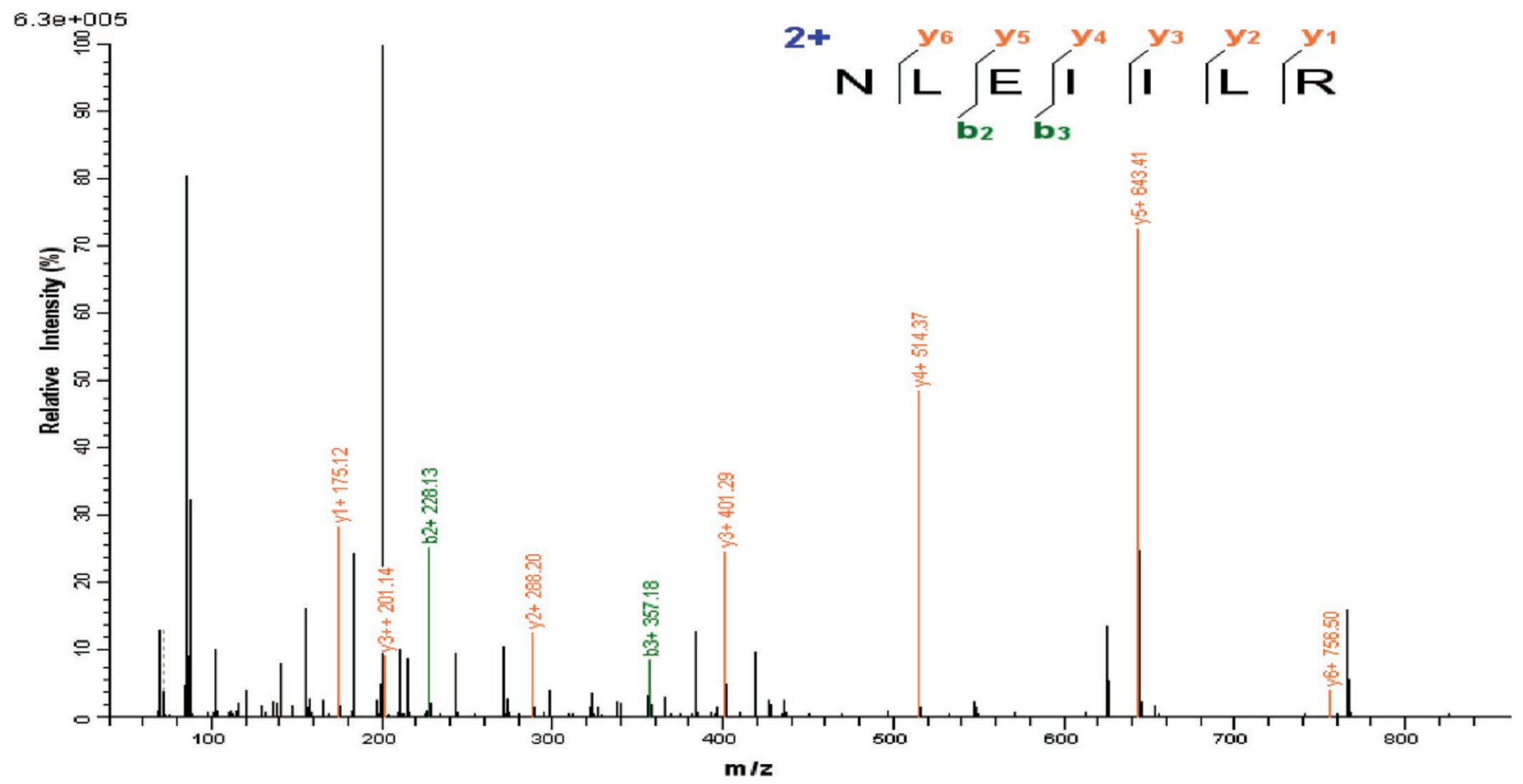

Figure 4. The liquid chromatography-electrospray ionization tandem mass spectrometry (LC-ESI MS/MS) spectrum of double-charged ion with $\mathrm{m} / z$ 435.77. Following sequence interpretation and database searching, the LC-ESI MS/MS spectrum of ion with $\mathrm{m} / z 870.54$ was matched to peptide NLEIILR. The peptide sequences are shown with the fragment (b, y) ions observed in the spectra. Color version available online. 
(A)

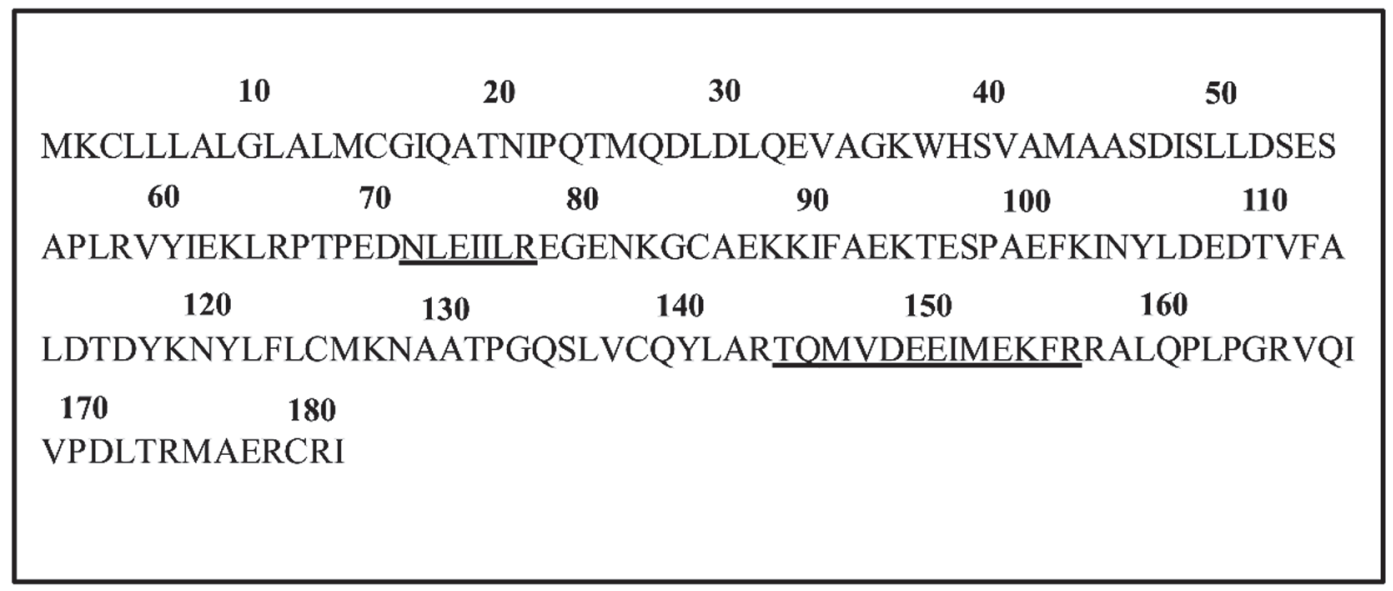

(B)

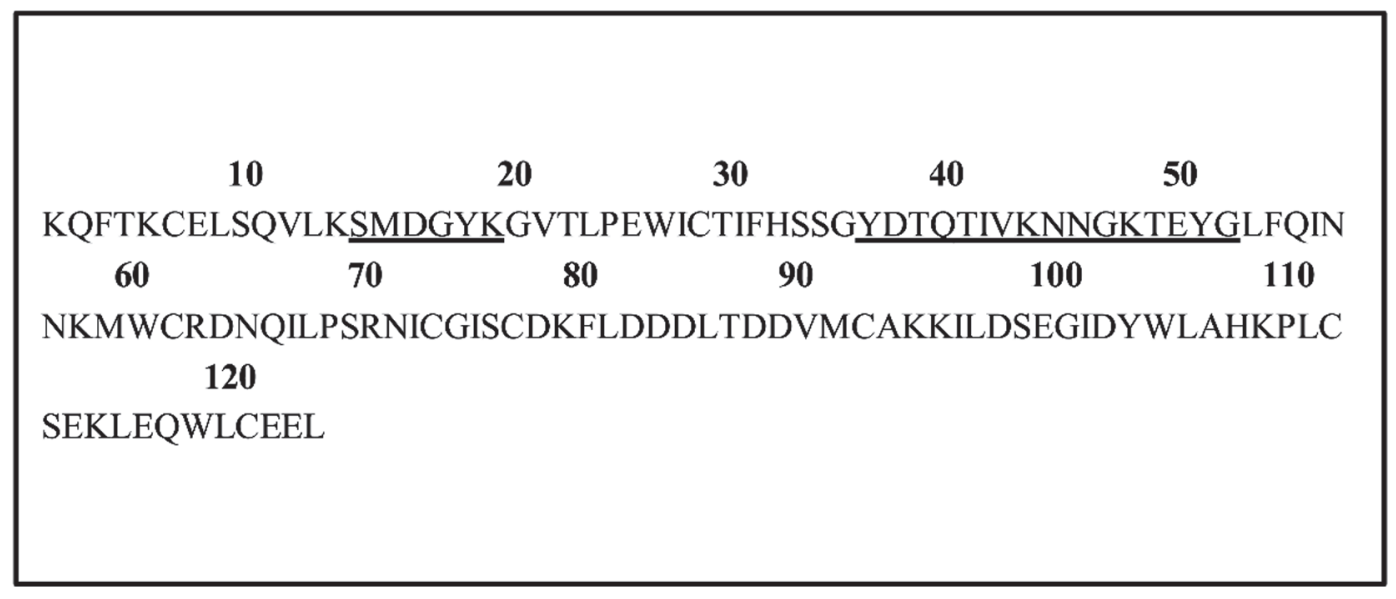

Figure 5. Mature AA sequences of mare $\beta$-LG-1 (UniProt KB database accession number P02758; A) and $\alpha$-LA A (UniProt KB database accession number P08334, http://www.uniprot.org/; B). Peptide sequences identified in the mare whey hydrolysate fractions are underlined.

peptide Asn-Leu-Glu-Ile-Ile-Leu-Arg after simulated gastrointestinal digestion, which suggested that the DPP-IV inhibitory activity of the peptide could be retained under simulated gastrointestinal conditions. However, the DPP-IV inhibitory activity of Thr-GlnMet-Val-Asp-Glu-Glu-Ile-Met-Glu-Lys-Phe-Arg was improved by gastrointestinal enzyme treatment. This effect may be associated with the formation of new and smaller DPP-IV inhibitory peptides induced by

Table 2. The half-maximal inhibitory concenwtration $\left(\mathrm{IC}_{50}\right)$ values against dipeptidyl peptidase-IV (DPP-IV) of synthesized peptides NLEIILR, TQMVDEEIMEKFR, and diprotin A

\begin{tabular}{lc}
\hline Sample & $\mathrm{IC}_{50}(\mu M)$ \\
\hline NLEIILR & 86.34 \\
TQMVDEEIMEKFR & 69.84 \\
Diprotin A & 10.45 \\
\hline
\end{tabular}

Table 3. Simulated gastrointestinal stability of synthetic dipeptidyl peptidase-IV (DPP-IV) inhibitory peptides NLEIILR, TQMVDEEIMEKFR, and diprotin $\mathrm{A}^{1}$

\begin{tabular}{lcc}
\hline \multirow{2}{*}{ Sample } & \multicolumn{2}{c}{ DPP-IV inhibition (\%) } \\
\cline { 2 - 3 } & Before SG & After SG \\
\hline NLEIILR & $54.86 \pm 2.71^{\mathrm{a}}$ & $52.74 \pm 1.50^{\mathrm{a}}$ \\
TQMVDEEIMEKFR & $63.14 \pm 0.55^{\mathrm{b}}$ & $76.40 \pm 1.80^{\mathrm{a}}$ \\
Diprotin A & $38.77 \pm 0.90^{\mathrm{a}}$ & $37.61 \pm 0.45^{\mathrm{a}}$ \\
\hline
\end{tabular}

$\overline{\mathrm{a}, \mathrm{b}}$ Values in a row bearing different letters are significantly different $(P<0.05)$.

${ }^{1}$ Values are expressed as means $\pm \mathrm{SD}$ of 3 independent determinations. The DPP-IV inhibition activity of NLEIILR, TQMVDEEIMEKFR, and diprotin A was performed using $0.5 \mathrm{mg} / \mathrm{mL}, 0.5 \mathrm{mg} / \mathrm{mL}$, and $2 \mu \mathrm{g} / \mathrm{mL}$ (final assay concentration). SG: simulated gastrointestinal digestion. 
enzymatic-triggered cleavage of peptide bond cleavage. In agreement with our study, peptides derived from tuna cooking juice hydrolysates exhibits higher DPPIV inhibitory activity upon simulated gastrointestinal digestion (Huang et al., 2012). Taken together, these results indicated that 2 DPP-IV inhibitory peptides, Asn-Leu-Glu-Ile-Ile-Leu-Arg and Thr-Gln-Met-ValAsp-Glu-Glu-Ile-Met-Glu-Lys-Phe-Arg, isolated from mare whey may possess a potential effect in regulation of blood glucose and amelioration of type 2 diabetes.

Various studies have highlighted the role of the length of peptides, compositions, and sequences of AA in peptides on their DPP-IV inhibitory activities. Most dietary protein-derived DPP-IV inhibitory peptides described in the literature have a length of 2 to $8 \mathrm{AA}$ (Lacroix and Li-Chan, 2012); however, peptides larger than 13 residues have been reported as novel DPP-IV inhibitor (Huang et al., 2012). Our study showed that heptapeptide NLEIILR and tridecapeptide TQMVDEEIMEKFR possessed DPP-IV inhibitory activity, which suggested that DPP-IV inhibitory activity of peptides may be associated with the composition and sequence of AA rather than their length. The presence of hydrophobic AA and a Pro residue, especially a Pro in the second N-terminal residue within the sequence of peptides, is a typical characteristic of DPP-IV inhibitory peptides (Li-Chan et al., 2012). The Pro residue is present within the sequences of bovine whey proteinderived DPP-IV inhibitory peptides as the second or third N-terminal residue (Silveira et al., 2013; Lacroix and Li-Chan, 2014). Peptides identified from goat milk casein display DPP-IV inhibitory activity, characterized by the presence of Pro residue and large amounts of hydrophobic AA, such as Phe, Tyr, Leu, Ile, Trp, Val, and Met (Zhang et al., 2015). In the present study, the 2 DPP-IV inhibitory peptides from mare whey protein were composed of many hydrophobic AA residues, such as Leu, Ile, Met, Phe, and Val. However, the AA sequences of DPP-IV inhibiting peptides generated from dietary proteins depend, to a very great extent, on hydrolysis conditions such as the types of proteases. Thus, whether DPP-IV inhibiting peptides containing Pro in the second N-terminal residue exist in the mare whey protein hydrolysates produced by other proteases need to be further investigated. In addition, it is reported that the peptides with acidic isoelectric point are capable of blocking the formation of DPP-IV dimers by locating at the dimerization interface, inhibiting DPP-IV activity (Velarde-Salcedo et al., 2013). In the present study, the heptapeptide NLEIILR and tridecapeptide TQMVDEEIMEKFR with a predicted acidic isoelectric point ( $\mathrm{p} I 6.00$ and 4.41, respectively, http://web.expasy.org/compute_pi/) showed potent DPP-IV inhibitory activity. However, the binding modes of these peptides with the DPP-IV enzyme need to be investigated via molecular docking simulations in our further study.

\section{CONCLUSIONS}

Peptides with DPP-IV inhibitory activity were successfully prepared from mare whey proteins through papain hydrolysis. Two novel peptides Asn-Leu-GluIle-Ile-Leu-Arg and Thr-Gln-Met-Val-Asp-Glu-Glu-IleMet-Glu-Lys-Phe-Arg were identified from mare whey protein hydrolysates, and showed good DPP-IV inhibitory activity in vitro. The DPP-IV inhibitory activity of the 2 peptides was retained or even improved after simulated gastrointestinal enzyme treatment. These results suggested that peptides derived from mare whey may possess potential in the management of type 2 diabetes. Further studies using Caco- 2 cells/islet $\beta$-cells and animal model systems are also necessary to evaluate DPP-IV inhibitory activity of the peptides derived from mare whey.

\section{ACKNOWLEDGMENTS}

We are grateful for the financial support for this work by Key Projects in the National Science \& Technology Pillar Program during the Twelfth Five-year Plan Period (2013BAD18B12-05; China), the National Natural Science Foundation of China (Grant No. 31371753), and National Dairy Industry Technology System-Beijing Innovation Team (NDITS-BIT; China).

\section{REFERENCES}

Alonso-Magdalena, P., A. B. Ropero, S. Soriano, I. Quesada, and A. Nadal. 2010. Bisphenol-A: A new diabetogenic factor. Hormones 9:118-126.

Boots, J. W. P. 2012. Protein hydrolysate enriched in peptides inhibiting DPP-IV and their use. US Pat. No. 8273710 B2.

Brandelli, A., D. J. Daroit, and A. P. F. Corrêa. 2015. Whey as a source of peptides with remarkable biological activities. Food Res. Int. 73:149-161.

de Carvalho-Silva, L. B., M. T. B. Pacheco, R. Bertoldo, C. de Carvalho Veloso, L. C. Teodoro, A. Giusti-Paiva, P. Lollo, and R. Soncini. 2014. Anti-inflammatory activities of enzymatic (alcalase) hydrolysate of a whey protein concentrate. Afr. J. Biotechnol. 11:2993-2999.

Deshpande, A. D., M. Harris-Hayes, and M. Schootman. 2008. Epidemiology of diabetes and diabetes-related complications. Phys. Ther. 88:1254-1264.

Drucker, D. J. 2006. The biology of incretin hormones. Cell Metab. $3: 153-165$

El-Salam, M. A., and S. El-Shibiny. 2013. Bioactive peptides of buffalo, camel, goat, sheep, mare, and yak milks and milk products. Food Rev. Int. 29:1-23.

Finete, V. L., M. M. Gouvêa, F. F. de Carvalho Marques, and A. D. Netto. 2013. Is it possible to screen for milk or whey protein adulteration with melamine, urea and ammonium sulphate, combining Kjeldahl and classical spectrophotometric methods? Food Chem. 141:3649-3655. 
Fox, P. F., and T. Uniacke. 2010. Chemical and physico-chemical properties of equid milk. Page 39 in Proceedings of the 61st Annual Meeting of the EAAP, Heraklion, Greece. August 23-27, 2010. Wageningen Academic Publishers, Wageningen, the Netherlands.

Guariguata, L., D. R. Whiting, I. Hambleton, J. Beagley, U. Linnenkamp, and J. E. Shaw. 2014. Global estimates of diabetes prevalence for 2013 and projections for 2035. Diabetes Res. Clin. Pract. 103:137-149

Hatanaka, T., Y. Inoue, J. Arima, Y. Kumagai, H. Usuki, K. Kawakami, M. Kimura, and T. Mukaihara. 2012. Production of dipeptidy peptidase IV inhibitory peptides from defatted rice bran. Food Chem. 134:797-802.

Higuchi, N., T. Hira, N. Yamada, and H. Hara. 2013. Oral administration of corn zein hydrolysate stimulates GLP-1 and GIP secretion and improves glucose tolerance in male normal rats and GotoKakizaki rats. Endocrinology 154:3089-3098.

Holst, J. J., and J. Gromada. 2004. Role of incretin hormones in the regulation of insulin secretion in diabetic and nondiabetic humans. Am. J. Physiol. Endocrinol. Metab. 287:E199-E206.

Hsieh, C. H. T. Y. Wang, C. C. Hung, M. C. Chen, and K. C. Hsu. 2015. Improvement of glycemic control in streptozotocin-induced diabetic rats by Atlantic salmon skin gelatin hydrolysate as the dipeptidyl-peptidase IV inhibitor. Food Funct. 6:1887-1892.

Huang, S. L., C. Jao, K. Ho, and K. Hsu. 2012. Dipeptidyl-peptidase IV inhibitory activity of peptides derived from tuna cooking juice hydrolysates. Peptides 35:114-121.

International Diabetes Federation. 2013. International Diabetes Federation Diabetes Atlas, 6th ed. International Diabetes Federation, Brussels, Belgium.

Jakubowicz, D., and O. Froy. 2013. Biochemical and metabolic mechanisms by which dietary whey protein may combat obesity and Type 2 diabetes. J. Nutr. Biochem. 24:1-5.

Karasik, A., P. Aschner, H. Katzeff, M. J. Davies, and P. P. Stein. 2008. Sitagliptin, a DPP-4 inhibitor for the treatment of patients with type 2 diabetes: A review of recent clinical trials. Curr. Med. Res. Opin. 24:489-496.

Khan, M. A., C. Deaton, M. K. Rutter, L. Neyses, and M. A. Mamas. 2013. Incretins as a novel therapeutic strategy in patients with diabetes and heart failure. Heart Fail. Rev. 18:141-148.

Lacroix, I. M., and E. C. Li-Chan. 2012. Evaluation of the potential of dietary proteins as precursors of dipeptidyl peptidase (DPP)IV inhibitors by an in silico approach. J. Funct. Foods 4:403-422.

Lacroix, I. M., and E. C. Li-Chan. 2013. Inhibition of dipeptidyl peptidase (DPP)-IV and $\alpha$-glucosidase activities by pepsin-treated whey proteins. J. Agric. Food Chem. 61:7500-7506.

Lacroix, I. M., and E. C. Li-Chan. 2014. Isolation and characterization of peptides with dipeptidyl peptidase-IV inhibitory activity from pepsin-treated bovine whey proteins. Peptides 54:39-48.

Li-Chan, E. C., S. Hunag, C. Jao, K. Ho, and K. Hsu. 2012. Peptides derived from Atlantic salmon skin gelatin as dipeptidyl-peptidase IV inhibitors. J. Agric. Food Chem. 60:973-978.

Malacarne, M., F. Martuzzi, A. Summer, and P. Mariani. 2002. Protein and fat composition of mare's milk: some nutritional remarks with reference to human and cow's milk. Int. Dairy J. 12:869-877.

Martuzzi, F., and F. Vaccari Simonini. 2010. Advances on equine milk and derivatives for human consumption. Page 40 in Proceedings of the 61st Annual Meeting of the EAAP, Heraklion, Greece. August 23-27, 2010. Wageningen Academic Publishers, Wageningen, the Netherlands.

Nauck, M. A., T. Vilsbøll, B. Gallwitz, A. Garber, and S. Madsbad. 2009. Incretin-based therapies: Viewpoints on the way to consensus. Diabetes Care 32:S223-S231.

Nongonierma, A. B., and R. J. FitzGerald. 2013. Dipeptidyl peptidase IV inhibitory properties of a whey protein hydrolysate: Influence of fractionation, stability to simulated gastrointestinal digestion and food-drug interaction. Int. Dairy J. 32:33-39.

Nongonierma, A. B., and R. J. FitzGerald. 2014. Susceptibility of milk protein-derived peptides to dipeptidyl peptidase IV (DPP-IV) hydrolysis. Food Chem. 145:845-852.
Pal, S., and V. Ellis. 2010. The chronic effects of whey proteins on blood pressure, vascular function, and inflammatory markers in overweight individuals. Obesity (Silver Spring) 18:1354-1359.

Pratley, R. E., S. Jauffret-Kamel, E. Galbreath, and D. Holmes. 2006. Twelve-week monotherapy with the DPP-4 inhibitor vildagliptin improves glycemic control in subjects with type 2 diabetes. Horm. Metab. Res. 38:423-428.

Rad, J. S., M. H. Alfatemi, and M. S. Rad. 2013. Horse milk; the composition, equine milk proteins, milk allergy and homology between mammal species with horse. Br. Biomed. Bull. 1:1-4.

Reid, T. 2012. Choosing GLP-1 receptor agonists or DPP-4 inhibitors: Weighing the clinical trial evidence. Clin. Diabetes 30:3-12.

Shertzer, H. G., S. E. Woods, M. Krishan, M. B. Genter, and K. J. Pearson. 2011. Dietary whey protein lowers the risk for metabolic disease in mice fed a high-fat diet. J. Nutr. 141:582-587.

Silveira, S. T., D. Martínez-Maqueda, I. Recio, and B. HernándezLedesma. 2013. Dipeptidyl peptidase-IV inhibitory peptides generated by tryptic hydrolysis of a whey protein concentrate rich in $\beta$-lactoglobulin. Food Chem. 141:1072-1077.

Tulipano, G. V. Sibilia, A. M. Caroli, and D. Cocchi. 2011. Whey proteins as source of dipeptidyl dipeptidase IV (dipeptidyl peptidase-4) inhibitors. Peptides 32:835-838.

Uchida, M., Y. Ohshiba, and O. Mogami. 2011. Novel dipeptidyl peptidase-4-inhibiting peptide derived from $\beta$-lactoglobulin. J. Pharmacol. Sci. 117:63-66.

Uniacke-Lowe, T., T. Huppertz, and P. F. Fox. 2010. Equine milk proteins: Chemistry, structure and nutritional significance. Int. Dairy J. 20:609-629

Van, A. A., T. M. J. C. Beelen, Z. W. L. A. Van, G. W. H. Van, J. H. Buikema, and J. W. P. M. Nelissen. 2009. Egg protein hydrolysates. WO Pat. No. 2009128713 A1.

Velarde-Salcedo, A. J., A. Barrera-Pacheco, S. Lara-González, G. M. Montero-Morán, A. Díaz-Gois, E. G. de Mejia, and A. P. B. de la Rosa. 2013. In vitro inhibition of dipeptidyl peptidase IV by peptides derived from the hydrolysis of amaranth (Amaranthus hypochondriacus L.) proteins. Food Chem. 136:758-764.

Walsh, D. J., H. Bernard, B. A. Murray, J. MacDonald, A. Pentzien, G. A. Wright, J. Wal, A. D. Struthers, H. Meisel, and R. J. FitzGerald. 2004. In vitro generation and stability of the lactokinin $\beta$-lactoglobulin fragment (142-148). J. Dairy Sci. 87:3845-3857.

Wang, X., L. Wang, X. Cheng, J. Zhou, X. Tang, and X. Mao. 2012 Hypertension-attenuating effect of whey protein hydrolysate on spontaneously hypertensive rats. Food Chem. 134:122-126.

Yin, L. M., M. A. Edwards, J. Li, C. M. Yip, and C. M. Deber. 2012 Roles of hydrophobicity and charge distribution of cationic antimicrobial peptides in peptide-membrane interactions. J. Biol. Chem. 287:7738-7745

Zambrowicz, A., E. Eckert, M. Pokora, Ł. Bobak, A. Dąbrowska, M. Szołtysik, T. Trziszka, and J. Chrzanowska. 2015. Antioxidant and antidiabetic activities of peptides isolated from a hydrolysate of an egg-yolk protein by-product prepared with a proteinase from Asian pumpkin (Cucurbita ficifolia). RSC Advances 5:10460-10467.

Zhang, J., C. Xue, T. Zhu, A. Vivekanandan, S. Pennathur, Z. A. Ma, and Y. E. Chen. 2013. A tripeptide Diapin effectively lowers blood glucose levels in male type 2 diabetes mice by increasing blood levels of insulin and GLP-1. PLoS One 8:e83509.

Zhang, Y., R. Chen, H. Ma, and S. Chen. 2015. Isolation and identification of dipeptidyl peptidase IV-inhibitory peptides from trypsin/chymotrypsin-treated goat milk casein hydrolysates by 2DTLC and LC-MS/MS. J. Agric. Food Chem. 63:8819-8828.

Zhang, Y., R. Chen, F. Zuo, H. Ma, Y. Zhang, and S. Chen. 2016. Comparison of dipeptidyl peptidase IV-inhibitory activity of peptides from bovine and caprine milk casein by in silico and in vitro analyses. Int. Dairy J. 53:37-44. 